DOI: https://doi.org/10.47405/mjssh.v6i6.816

\begin{tabular}{|c|c|}
\hline 4.581 & Malaysian Journal of Social Sciences and Humanities (MJSSH) \\
\hline $\begin{array}{l}\text { Malaysian Journal of } \\
\text { Social cciences and }\end{array}$ & Volume 6, Issue 6, June 2021 \\
\hline (MJ-SSH) & e-ISSN : 2504-8562 \\
\hline & $\begin{array}{l}\text { Journal home page: } \\
\text { www.msocialsciences.com }\end{array}$ \\
\hline
\end{tabular}

\title{
An Evaluation of Local Government and SURE-P Implementation Challenges on Rural Community Development: A Case of Selected Local Government in Niger State, Nigeria
}

\author{
Abubakar Mohammed Jibrin ${ }^{1}$, Azmil Muhammad Tayeb ${ }^{1}$, Siti Zuliha Razali ${ }^{1}$ \\ ${ }^{1}$ School of Social Sciences, University Sains Malaysia (USM) \\ Correspondence: Abubakar Mohammed Jibrin (abubakarjibrinkutigi@gmail.com)
}

\begin{abstract}
Rural areas play an essential role in the national economy, the environment, and society, contribute to the preservation of cultural heritage and the sustainable income of peasants in the rural areas in Nigeria hence, diverse strategies for rural community development. However, rural community development efforts by local governments and policies hindered by challenges. SURE-P was an intervention by the government of Nigeria after the partial removal of the subsidy and resolved to invest the proceeds in pursuing rural development across Nigeria. Rural development is a multifaceted phenomenon that requires a policy with multi-side sword effects in curbing the challenges. The research objective was to examine the challenges of local government and SURE-P implementation on rural community development in the selected local government in Niger, Nigeria. The study employed primary data collection and qualitative analytical method analysis. The research founds that SURE-P implementation challenges hindered the local government's efforts in meeting the rural community development objective. It is recommended that, need for thorough community's needs identification, community participation, and adequate funding with a holistic process devoid of political interference as a viable mechanism for curbing rural development challenges.
\end{abstract}

Keywords: policy implementation, rural, rural development, SURE-p, local government

\section{Introduction}

Nigeria is a federal system nation with the division of powers by the constitution among the national, state, and local levels of government. Local government is the nation's lower tier of administration. It's referred to as grassroots administration. The most critical level of government to achieve sustainable economic and social development is the local government. National development targeted to begin from the grassroots level as local government is a critical tool in rural change and social and economic distribution approach (Kusakabe, 2013).

Not fewer than 75 percent of the Nigerian population cohabit in rural areas in which necessary infrastructure and social needs are lacking. On this basis, the reform of the local government began in 1976, as more tasks, duties, and financial resources are allotted to local governments to solve the gap of rural problems (Aliyu \& Amadu, 2017). As a level of government, the local government retains its position as the nearest levels of government to the citizens to take charge of the development of the rural communities. (Bello, 2014). A local government is responsible for providing necessary economic and social infrastructure to the local community and also serve as a training base for participation in 
democracy (Sikander, 2015). The development of the rural communities and local governments will, therefore, instantly incorporate into the country's development. Though, the lower levels of government have experienced several challenges that have jeopardized the essence of the grass-root government whose mandate derived from the constitution according to its development objective (Idike, 2014). Such challenges emanated an intentional attempt to stalk the progress of development at the lower level government of a nation. It has, therefore, subdued the local governments in the performance in their legally allowed responsibilities of influencing development from the rural levels (Idike, 2014). It is, therefore, the objective of this paper to discuss the issues confronting local government and the opportunities for vibrant local community development and national development. A case study approach applied with the aid of qualitative data from a primary source through the unstructured interview. The local government set up to facilitate the fair and secure provision of resources to residents at the local level. Therefore, the development would be meaningless if it does not have an impact on rural dwellers (Lawal, 2014). Local governments set up to guarantee grassroots development. The purpose of local government includes the function of fostering a sense of unity, stability, and satisfaction among its citizens (Madumo, 2015). Nigeria is a nation with a complex sociopolitical history, a range of communities, various languages, and unique needs and incomes. Hence, the local government's role in fostering peace and maintaining regional multiplicity cannot be unnoticed. Despite the significance of local government, there have been issues with the execution of its functions, particularly in the areas of grassroots service delivery (Arthur, 2016).

The Subsidy Reinvestment and Empowerment Program (SUR-EP) is an initiative funded by the federal government's retained funds as savings after a partial reduction of petroleum subsidies (Amakom, 2013). The implementation of the SUR-P Subsidy Reinvestment and Empowerment Program aimed at alleviating the difficulties incurred by the reduction of fuel subsidies by the federal government sure-P has therefore funded to address a broad range of infrastructure needs and safety projects across the country in areas such as education, entrepreneurship, healthcare facilities, road, and bridge construction, transport, agricultural empowerment, job creation, poverty reduction, environmental protection, and sustainability, etc. (Anazodo, Ezenwile, \& Chukwurah, 2014).

The biggest challenge faced by most Nigerian local governments is the lack of adequate resources to execute many development programs. (Boris, 2015). Though there has been an amazing upgrade and rise in the overall amount of funds accessible to local government in Nigeria since the oil price boom on the international market (Khemani, 2001). The lack of adequate funding may justify by the fact that the monthly allocations of local government federations were seized by state governors, in some cases used during the campaign and shared among political leaders and family members (Eme, Izueke, \& Ewuim, 2013).

Despite the massive funding of the successive Nigerian Government for rural growth, the rural development effort remains an illusion, and the local governments have been struggling to fulfill their responsibilities (Ijeoma \& Nzewi, 2016). Local government, as Nigeria's third-tier governance, was intended to serve as a platform for rapid and continuing grassroots development. However, the expectation of quick and sustainable development was a mirage, because subsequent councils had struggled extremely in nearly all aspects of their mandate (Isa, 2016). In addition to the widespread exploitation and abuse of funds already found in most local councils in Nigeria, the money used for social development programs are used to benefit politicians and party rulers (Okafor, Chukwuemeka, \& Udenta, 2015). Rural areas are the main and most significant component of the population of Nigeria. Ajaero and Onokala (2013), despite the large-scale rural poverty induced by the failure of local governments to function efficiently as the third level of government with legislative authority to address cultural-economic issues, the rural community contributes tremendously to general national development in Nigeria. Nigerian local governments must therefore commit themselves to sustainable rural development on the basis of the above criteria.

The state governors suspected of dampening local government funds and allocating much fewer than \#20 million to each council to cover salaries and their operational expenses (Kizito \& Fadila, 2015). However, corruption has compounded the lack of funding and has posed an obstacle to the successful provision of services in rural areas (UN-Habitat, 2015). This article, therefore, aims to discuss this 
challenge of insufficient financing, which has posed a significant challenge to local government development and SURE-P Implementation of rural community creation. As a consequence, the allocation to local government should go directly to their hands for effective governance, rapid economic development, and successful delivery of services.

\section{Literature Review}

The study of local government development as a form of governance in Nigeria would not be justified until it followed by an inquiry into the philosophic thought around the local government system.(Bolatito \& Ibrahim, 2014). The structure, nature, and roles of the local government shaped by the political views of those with the power and jurisdiction to decide about the key features of the local government system (Chima \& Abdulhamid, 2015).

Before the reforms of 1976, the system of local government has no uniformity in the system, and then there was a different level of development. The introduction of local government reforms by General Obasanjo's military administration in by 1976, the institutional framework of the system became standardized. The reforms adopted a new multipurpose local governance structure (Ikeanyibe, 2018). The problem of funding remains a big obstacle. Many of the rural development programs are too complicated without a consistent and established means of financing, The Homes for All, Universal Basic Education (UBE) situations, and so on are obvious instances (Shah \& Shah, 2009).

Another challenge for rural development is internal violence, spanning from ethnic and religious regional problems that do not offer an atmosphere for the execution of sustainable development projects in these regions (Caiado, Leal Filho, Quelhas, de Mattos Nascimento, \& Ávila, 2018). Corruption is another challenge that presents a major obstacle to rural development. People who are to implement construction projects in rural areas lack competence, accountability, and transparency (Aladwani, 2016). Government finances for rural infrastructures have depleted by European and American banks (Infrastructure, 2019). The lack of political will and determination, political stability, and lack of interest of program beneficiaries with the majority of people residing in abject poverty is an obstacle for rural development in Nigeria (Aminu \& Onimisi, 2014).

A further obstacle is the lack of consistency in the program. Most policies implemented died with the government development initiatives such as Operation Feed the Nation, Green Revolution, Free, and Compulsive Primary Education, low-cost housing strategies that have a positive impact on unsustainable rural residents are good examples (Hussaini, 2014).

Other problems include Bad infrastructure, growing population increase, a vicious cycle of poverty, rising rates of illiteracy, weak social expectations participation, local politics, and rural-urban migration (Johnson \& Ifeoma, 2018). Implementation is another obvious challenge; due to lack of proper supervision, certain policies and programs are implemented arbitrarily.

\section{Challenges facing Local Governments}

The problem of autonomy and excessive political interference is one of the most significant challenges faced by the local government today in Nigeria. The attempt for the financial and political autonomy of the local government has been in effect for a long time and proceeded to obtain a hostile answer from the State House of Assembly for approval on behalf of the Government of the State. These State Governments shall make use of Section 7(1) of the Federal Republic of Nigeria Constitution of 1999 (as amended) which provides that;

'The local government which is elected constitutionally by the populace in line with this constitutional provision, and therefore, the Government of every State shall subject to Section 8 of this Constitution, ensure their existence under a law which provides for the establishment, structure, composition, finance, and function of such council". The plurality of Nigerian state governments is involved in the height of local government activity (Ahmad, 2013). 
One type of corruption or another is applied to local government finance by excess deductions for payment of primary school teacher wages, fraudulent state / local government joint project execution, election fundraising, denial of local government constitutional duties, and execution by political associates advisors, and non-payment of pensioners (Walker \& Andrews, 2015; Agba, Akwara \& Idu, 2013). Democratic leaders set up their associates as caretakers' committees, without the consent of the citizens, or politically upright ones, to combat the control of the state government that engages in undesirable actions. Nigeria's various rural development policies targeted at enhancing living standards in rural areas to counter rural-urban migration. Such initiatives reflect the efforts of numerous governments and non-governmental organizations (NGOs) to set up development institutions (Paul, Agba, \& Chukwurah, 2014). Despite the different rural development policies implemented by successive governments in Nigeria and the enormous financial, material resources committed, there was non-impact on rural areas because these policies mostly die with the government that initiated them without having any effect on the rural population (Ering, Otu, \& Archibong, 2014).

\section{Theoretical Context}

John Rawls' Distributive Theory of Social Justice adopted for this study (J Rawls, 1971) The theoretical status of this study emerged from the policy implementation. John Rawl's distributive theory of justice and fairness is an ethical philosophy whose basic principles can catch the meaning of what comprises the ideology of social justice adapted for this study. (Miller, 1999; J Rawls, 1971; Roemer, 2008; Amartya Kumar Sen, 2009). Rawls argues that all that society requires to be is equitable. According to Rawls, a fair society is one built on principles. Values are the best interpretation of a social system not based on specific desires or moral doctrine.

Applied to this research, SURE-P was a policy initiated by the federal government of Nigeria, in particular, to be just and fair in reinvesting the proceeds from the partial withdrawal of the subsidy by providing critical infrastructure to communities across the 774 local governments through the 36 states and Nigeria's federal capital territory. The SURE-P implementation conformed to the theory of John Rawls. SURE-P is a formulation of a social system based on the country's general interest to invest in providing rural communities in Nigeria with infrastructure that is critical to the national economic development. Nevertheless, this study, focused on the fundamental components of the theory of social justice, reveals how Rawl's hypothetical principle of justice and fairness based on a strong notion of equality. In a hypothetical case, justice better interpreted as equity in terms of equality (Daniels, 1989; Amartya K Sen, 2000; Van Lange, 1999; John Rawls, 2009). According to Rawls (1971), all primary social goods-freedom and opportunity, income, and wealth, and how they distributed equally unless an unequal distribution of any or all these goods is to the advantage of the least favored. The theory spoke about equity, justice and fairness of a system based on fairness regarding the implementation of SURE-P, particularly among the selected local government from Niger state, Nigeria, making it applicable to the study

\section{Methodology}

A qualitative method applied to this study was to explore the "local government" and the "Sure-p" challenges to rural community development in the selected Nigerian state local governments. A qualitative approach has been used in case study research to enhance understanding of policymaking and implementation (Saetren, 2005). The thematic analytical procedures were applied in line with the study's methodological framework. The thematic analysis consists of a method to identify, analyze, and report patterns (themes) within the data. The data set is organized and described in detail (Bogdan \& Biklen, 1998). Nevertheless, it also often interprets different aspects of the subject of the analysis (Virginia Braun \& Victoria Clarke, 2006).

The data for this study is from a sample of 13 SURE-P desk officers from six (6) selected local government authorities. government viz., Bida, Lavun, Chanchaga, Bosso, Kontagora, and 
Wushishi in Niger State, Nigeria. Saunders et al. (2018) acknowledged that ten and above could be engaged in an interview to allow theoretical saturation, and this will help minimize the chances of creating a theory based on insufficient data. This also interprets various aspects of the focus of the study. Selection based on a purposeful sampling technique; the researcher has control over the subjects in purpose sampling; Population sampling ensures precision than testing the entire population (Guetterman, 2015).

In all, this study interviewed 13 participants, all-male and local government officials, appointed as SURE-P desk officers to coordinate the implementation of SURE-P across communities. within their respective local governments, one of whom is the State SURE-P coordinator responsible for the implementation of SURE-P throughout the state.

Data were collected on weekdays and weekends, and the comfort of the participants considered in ensuring that all participants in this study interviewed. Nevertheless, the focus of this study was on the "local government" and the state "SURE-P" coordinators, who were the main actors in the implementation of SURE-P in the selected local government of Niger state. Nigeria. Data obtained by the researcher using an unstructured interview methodology. The researcher made clear the aim and the objective first and then received the permission of the participant for the interview and the audio recording of the conversation. The interviews carried out at the various secretariats of the selected local governments.

The constraints of local governance and the introduction of Sure-p in the rural community development context have driven the formulation of questions for the interview, but questions not restricted to variables described from this perspective. There was an opportunity to discuss and probe the perspectives of the participants throughout the interview process. Many of the questions asked the participants were: How has SURE-P addressed rural community development challenges in this LGA? How should a rural community development program be implemented? How can other challenges of rural community development be addressed?

All the participants spoke in English; the interviews are recorded and transcribed. The interviews took about 15 to 25 minutes. After transcription, the process of coding was by using thematic analysis procedures by V. Braun and V Clarke (2006). The researcher had familiarized himself with the data generated during the interview in the first stage. The initial code generated; the themes identified from the data; the researcher then reviewed the generated themes. The themes were defined and given their names. The researcher identified themes and named the generated themes. Finally, the concepts used to answer questions about the study. The codes compared to the variables discussed in the local government challenges and the context of Sure-p implementation (SURE-P implementation, implementation challenges, and rural community development challenges), for example, when the participants speak about the challenges. The study performed three times (one for each researcher), and the codes were verified to maintain accuracy in the data analysis method. From this process, different features of the experience could be uncovered.

\section{Findings}

This section was structured based on four main themes identified in the data analysis, i.e.,' inadequate funding,' political influence" local inclusion and needs assessment.' The first theme focuses on the different meanings of inadequate funding and the second theme explores the effect of political influence while the third theme explores local inclusion while the fourth theme focuses on the assessment of the need.

\section{SURE-P implementation}

To explore the process of implementing Sure-p as encountered by the participants. Many appreciated the full benefits of Sure-p interventions such as healthcare services and primary healthcare center construction in many communities, transportation and road construction, educational support, 
empowerment programs as part of SURE-P interventions to local governments. They lamented the way the SURE-P Program was implemented. Over half of the participants viewed SURE-P intervention as a proper development. We believe it will achieve greater effectiveness if it is completely institutionalized when the needs of the local people who are the recipients well-identified and prioritized by programs and included in the implementation process. Of these participants, 75 percent regretted the SURE-P intervention implementation process. He explained:

Sure-p in Bida local government is being coordinated and implemented through the local government desk officers with the assistance of ward development officers and other ad hoc officials. We receive proposals from the communities based on their needs and sent them to the state office for approval. (P1-Bida Sure-P Desk Officer I)

Similarly, another interviewee from lavun local government stated:

SURE-P implementation was in every local government not only in my local government through us, the desk officers in all the local governments. Members of the community submit their project request to our desk, after the project awarded to contractors, it's our duty to monitor the progress and make reports. (P4- Lavun Ward Development Officer)

When the researcher asked the respondent from Bosso local government about sure-p implementation. He stated:

we coordinated the program from the beginning till the end, we ensure the success of the program, but the state approves all works. (P8-Bosso Ward Development Officer)

\section{The challenges towards the SURE-P Implementation}

Participants attached significant importance to SURE-P interventions as a way of improving' people's living standards and communities by various interferences. However, implementation has some challenges.70\% of participants clarified that SURE-P enforcement had been negatively affected by some problems, such as political influence on the behavior of politicians who hijack the process in favor of their party men and their families. (Bida Ward Development officer) specifically said:

Leadership influence by the politicians who like to favor their people in the awards of contracts hinder the process, many other areas require government attention. Still, the funds are not enough to give attention to those areas, and you know we can do just little without funds. When asking the participants about the challenges with the Sure-p implementation. One participant explicitly stated:

There are challenges in times of funds, low-level grassroots awareness about the SURE-P activities, the issues of misappropriation, and favors to contractors by top officials are also there. Low-level grassroots awareness about the SURE-P activities. (P3-Lavun Desk Officer I)

The Sure-p intervention intended to mitigate the hardship that may affect the plight of the poor masses especially, the vulnerable at the rural areas hence, the provision of critical infrastructures to rural communities for their development and improving the quality of the lives of the people; challenges hindered the execution. one of the interviewees lamented:

Some of the challenges towards the implementation of SURE-P in this local government include the late disbursement of funds. Contract inflations and awards to the political allies by the political leaders are some of the challenges. (P6-Chanchaga Ward Development Officer)

sequel to the research question, I asked one of the participants about the challenges towards the implementation of Sure-p in the local government. He explained: 
The late release of funds by the state to local governments which delay the work, there were also the challenges which include contract inflation by the political heads, but the main problem is that of awareness about what the Sure-p intend to do. (P8-Bosso Ward Development Officer)

\section{Rural Community Development Challenges}

About $60 \%$ of the participants explained there are challenges among rural community development in the area of funding, low awareness, and local involvement. Most explained that while the SURE-P program has built up youth capacity in various areas of skills acquisition, educational enrolment has increased, learning and educational materials have been given, among other items, in rural areas. The challenges to them have delayed the development of the communities within local governments. In response to the question posed by the researcher regarding the challenges of the rural community development in the local government, one of the interviewees clearly explained:

In our local government, we are facing many challenges, which include inadequate funding, unnecessary political intervention is also a factor; our politicians always control affairs because of their interest. For example, in times of appointments and contracts, they tell us what to do. Another challenge is the low inclusion of the community members who should benefit from the program. (P1-Bida Desk Officer I)

At Lavun local government, one of the respondents testified:

I think there are many things which supposed to be done to improve the lives of our people, but monies are not there to take care of everything. More so, the politicians have always interfered in the process, and they control everything from above. (P4-Lavun Ward Development Officer)

The governments of Nigerian in the present and past central, state, and local government levels formulated the right number of policies and programs with rural focus and implications for improving rural life. The participation by rural people in National development and progress; the introduction of Sure-p was in line with this spirit to promote national development through the rural community development approach. However, challenges are inevitable. Therefore, another participant stated:

Yes, the major challenge associated with rural development is funding because everything involves funds, and the fund is not adequate to provide everything. leadership problem is another challenge, for us, the desk officers, we are not given a full chance to perform without dictation by the leaders (P6-Chanchaga Ward Development Officer)

\section{Conclusion}

This paper explores the challenges of SURE-P implementation and rural community development in the selected local governments of Niger state, Nigeria. This study shows that political interference, inadequate funding, institutionalization problem low awareness, and lack of inclusion of the locals to participate in the process is a challenge. Implementations without assessment of the people's needs have indeed, constitute the stumbling block against the effective implementation of SURE-P and rural community development.

The exciting finding of this study is the exposure to the challenges. Mainly the issue of funding, which is very fundamental to the success of every program or policy, another aspect of it is findings on how the politicians politicized the process by influencing the award of contracts to favor their party men and their families and allies. According to the participants' experience, this challenge has affected the implementation of SURE-P and rural community development, especially the issue of insufficient funding, unnecessary interference. The study gives some insight 
into the challenges of the SURE-P implementation and other problems of the rural community development from the selected local governments for this study.

Based on the limitations set out above, this research not intended to extend to the broader community, but the expertise of the researchers is crucial in drawing up a plan to overcome the challenges. Of the SURE-P implementation and rural community development as mostly explained by the respondents. The participant's experience showed Bottom-Top Approach is the viable mechanism for rural development. It allows local inclusion and participation. It is also good getting an upward analysis of the allocations of councils. Local authorities to look inward for increased Internally generated Income (IGR). Make communities economically self-reliant and compliment the SURE-P intervention in talking about other challenges of the rural community development. There is also the need for the sustenance of this intervention because such experiences would contribute to the socio-economic wellbeing of the people, crime reduction, and rural community development in the selected local governments in Niger state, Nigeria.

Based on the limitations of this study, we wish to recommend for the extension of the scope of this study subsequently by increasing the coverage of case study or be reconducted in other areas with the same sample or consequently, applying the quantitative technique.

\section{References}

Agba, M. S., Akwara, A. F., \& Idu, A. (2013). Local government and social service delivery in Nigeria: a content analysis. Academic Journal of Interdisciplinary Studies, 2(2), 455-455.

Ahmad, A. A. (2013). Local government autonomy and its effectiveness in Nigeria. Journal of African \& Asian Local Government Studies, 2(1), 48-59.

Ajaero, C. K., \& Onokala, P. C. (2013). The effects of rural-urban migration on rural communities of southeastern Nigeria. International Journal of Population Research.

Aladwani, A. M. (2016). Corruption as a source of e-Government projects failure in developing countries: A theoretical exposition. International Journal of Information Management, 36(1), 105-112.

Aliyu, A. A., \& Amadu, L. (2017). Urbanization, cities, and health: the challenges to Nigeria-a review. Annals of African Medicine, 16(4), 149.

Amakom, U. (2013). Subsidy Reinvestment and Empowerment Programme (SURE-P) Intervention in Nigeria: An Insight and Analysis.

Aminu, I., \& Onimisi, T. (2014). Policy Implementation and The Challenges of Poverty Alleviation in Nigeria. Academic Journal of Interdisciplinary Studies, 3(4), 295.

Anazodo, R., Ezenwile, U., \& Chukwurah, D. C., Jr. (2014). The Impact of Oil Subsidy Removal on Infrastructural Development in Nigeria (2000-2012). Public Administration Research, 3(1). DOI:10.5539/par.v3n1p88

Arthur, D. D. (2016). Examining the Effects of Governance Challenges in Ghana's Local Government System: A Case Study of the Mfantseman Municipal Assembly. Journal of US-China Public Administration, 13(7), 454-465.

Bello, M. (2014). Intergovernmental relations in Nigeria: An assessment of its practice at the local government level. Journal of Poverty, Investment, and Development, 4, 66-76.

Bogdan, R., \& Biklen, S. (1998). Introduction to qualitative research in education. England: Pearson.

Bolatito, S., \& Ibrahim, B. (2014). Challenges of Local Government Administration in Nigeria; An Appraisal of Nigerian Experience. International Journal of Science and Research (IJSR), 3(7), $562-568$.

Boris, O. H. (2015). Challenges confronting local government administration inefficient and effective social service delivery: The Nigerian Experience. International Journal of Public Administration and Management Research, 2(5), 12-22.

Braun, V., \& Clarke, V. (2006). Using thematic analysis in psychology. Qualitative research in psychology, 3(2), 77-101. 
Caiado, R. G. G., Leal Filho, W., Quelhas, O. L. G., de Mattos Nascimento, D. L., \& Ávila, L. V. (2018). A literature-based review on potentials and constraints in the implementation of sustainable development goals. Journal of Cleaner Production, 198, 1276-1288.

Chima, P., \& Abdulhamid, O.-S. (2015). Local government administration in Nigeria: the search for relevance. Commonwealth Journal of Local Governance, 18, 181.

Daniels, N. (1989). Reading Rawls: critical studies on Rawls' A theory of justice: Stanford University Press.

Eme, O. I., Izueke, E., \& Ewuim, N. (2013). Local government and fiscal autonomy for local government In Nigeria. Rev Public Adm Manag, 7, 112-120.

Ering, S. O., Otu, J. E., \& Archibong, E. P. (2014). Rural Development Policies in Nigeria: A critical appraisal. International Journal of Education and Research, 2(9), 307-320.

Guetterman, T. C. (2015). Descriptions of sampling practices within five approaches to qualitative research in education and the health sciences. Paper presented at the Forum Qualitative Sozialforschung/Forum: qualitative social research.

Hussaini, M. (2014). Poverty alleviation programs in Nigeria: Issues and challenges. International Journal of Development Research, 4(3), 717-720.

Idike, A. N. (2014). Local Government and Sustainable National Development in Nigeria. European Scientific Journal, ESJ, 10(25).

Ijeoma, E., \& Nzewi, O. (2016). Work procedures application in municipal government: Perspectives from local government employees in South Africa. Journal of Public Administration, 51(1), 5872 .

Ikeanyibe, O. M. (2018). Uniformity in the local government system and the governance model in Nigeria. Journal of Asian and African Studies, 53(1), 147-161.

Infrastructure, S. A. s. R. I. (2019). Economic Development Rural Development Hubs Report. CONTEXT.

Isa, M. K. (2016). Nigerian local government system and governance: Lessons, prospects, and challenges for post-2015 development goals. In Developmental Local Governance (pp. 107126): Springer.

Johnson, K., \& Ifeoma, U. (2018). Rural development as a panacea for rural-urban migration in Nigeria. Art Human Open Acc J, 2(5), 241-244.

Khemani, S. (2001). Fiscal federalism and service delivery in Nigeria: The role of states and local governments. Prepared for the Nigerian PER Steering Committee, 24.

Kizito, E. U., \& Fadila, J. (2015). The Challenges of State and Local Government Joint Account and its impact on Rural Development in Nigeria. Retrieved March 7, 2015.

Kusakabe, E. (2013). Advancing sustainable development at the local level: The case of machizukuri in Japanese cities. Progress in Planning, 80, 1-65.

Lawal, T. (2014). Local government and rural infrastructural delivery in Nigeria. International Journal of Academic Research in Business and Social Sciences, 4(4), 139.

Madumo, O. S. (2015). Developmental local government challenges and progress in South Africa.

Miller, D. (1999). Principles of social justice: Harvard University Press.

Okafor, C., Chukwuemeka, E. E., \& Udenta, J. O. (2015). Developmental Local Government as a model for grassroots socio-economic development in Nigeria. AFRREV IJAH: An International Journal of Arts and Humanities, 4(2), 42-61.

Paul, O., Agba, M., \& Chukwurah, D. (2014). Rural development programmes and rural Underdevelopment in Nigeria: A rethink. International Journal of Public Administration and Management Research, 2(4), 1-14.

Rawls, J. (1971). A theory of justice. Cambridge, MA: Harvard University Press.

Rawls, J. (2009). A theory of justice: Harvard university press.

Roemer, J. E. (2008). Equality of opportunity. The New Palgrave Dictionary of Economics 1-8, 18111816.

Saetren, H. (2005). Facts and myths about research on public policy implementation: Out-of-Fashion, allegedly dead, but still very much alive and relevant. Policy Studies Journal, 33(4), 559-582.

Saunders, B., Sim, J., Kingstone, T., Baker, S., Waterfield, J., Bartlam, B., . . . Jinks, C. (2018). Saturation in qualitative research: exploring its conceptualization and operationalization. Quality \& Quantity, 52(4), 1893-1907. 
Sen, A. K. (2000). Social justice and distribution of income. HANDBOOKS IN ECONOMICS, 16, 59-86.

Sen, A. K. (2009). The idea of justice: Harvard University Press.

Shah, A., \& Shah, S. (2009). The new vision of local governance and the evolving roles of local governments. Journal of Public Administration, 3(1), 2-15.

Sikander, T. (2015). A theoretical framework of local government. International Journal of Humanities and Social Science, 5(6), 171-176.

UN-Habitat. (2015). The challenge of local government financing in developing countries. In: Author Nairobi.

Van Lange, P. A. (1999). The pursuit of joint outcomes and equality in outcomes: An integrative model of social value orientation. Journal of personality and social psychology, 77(2), 337.

Walker, R. M., \& Andrews, R. (2015). Local government management and performance: A review of evidence. Journal of public administration research and theory, 25(1), 101-133. 